development of bacteria-a point that cannot be doubted-they may not kill the spores, thus permitting the germs of disease to escape. There are no experiments (of which I am aware) to answer this objection. But there is reason to believe that pathogenic germs do not resist for a very long time when in unfavourable media; even in sewers, that are not over-filled and stagnant, and that are well ventilated, infection does not easily linger. If inside the sewers disinfection is complete, and bacterial growth checked, and all disease germs rendered inactive, until carried for away from all populous centres, I think we can leave it to air, and to the other natural agents, to ultimately destroy the surviving germs, or completely alternate their pathogenic qualities.

Amongst the mineral acids, hydrochloric would, of course, be the cheapest. But I think sulphuric acid ought to be preferred, nitric acid being too costly and too corrusive. Sulphuric acid does not attack easily calcareous cements ; and if the sewers have their walls well plastered, the action of a slight excess of sulphuric acid in the sewage would be very slight indeed. Cements, more resisting than plaster, could be prepared. Moreover, if some portions of teh sulphuric sewage get carried in the air, or are dried in the higher parts of the sewers, the germ-laden particles do not rid themselves of the acid by evaporation; on the contrary, the acid becomes more concentrated and active, and finally must disorgani-e and destroy the noxious germs. This is very important in preventing the effects of sewage air.

Since I88I Prof. Beilstein of St. Petersburg (Nature, vol. xxiii. p. 394), experimentally concluded that sulphuric acid is the best disinfectant, although he did not advise its use because of its corrosive action. Strange to say, Beilstein thought that, practically, aluminous sulphate was to be preferred to the free acid.

It is not only during the fear of cholera invasions, but at all times, that I would wish the sewage to be slightly acidified with sulphuric acid. Strict supervision should be maintained over all the sewers, to ascertain that the whole mass of flowing sewage is permanently acid. I am persuaded that this simple mode of disinfection would diminish considerably many infectious diseases.

During the cholera epidemic of $\mathbf{r} 884$, in Naples, I did my best, in a series of letters I then published, to persuade the sanitary authorities of this mode of disinfection. But a strange confusion of ideas was then prevalent in Naples. Through the goodwill of Prof. Cantani, Member of the Sanitary Commission, some trials of the method I proposed were done, but not in a complete and systematic manner. Such experiments cannot be done easily in Naples, and the results cannot be conclusive until the system of sewers is in good working order. Indeed, in some parts of the soil of Naples it is difficult to know of there is more sewage inside or outside the sewers. It is no easy problem to disinfect and cleanse such an impure soil, and it is indeed to be wondered that the ravages of cholera were so limited in 1884

My letters caused sulphuric acid to be used abundantly in the sewers and pozzi neri of Portici, Castellamare, Taranto, and, I believe, in other places; but this, like all other disinfections, was done under pressure of approaching cholera, and abandoned as soon as the danger passed, no observation being made to measure the influence of the sanitary method adopted on local infectious diseases. The defective system of sewers and of drainage in many Italian towns renders thorough disinfection scarcely possible, and prevents precision in testing any kind of disin. fection.

In English towns sewers are generally well arranged, and often well ventilated; and vital statistics have taken sufficient development to permit the testing of sanitary reforms. When it is proved (and I think the proof can be easily given) that the present systems of sewage disinfection are not sufficient to prevent entirely bacterial development in the sewers, these systems cannot be considered good. I venture to hope that beneficial results would soon become evident if the sulphuric acid disinfection of sewage were thoroughly applied in English towns.

Portici, August 20

ITALO Giglioli

\section{Ozone at Sea}

THE presence of this element in the atmosphere is alleged to be indicative of its healthiness, and it has been investigated on land frequently by observers with varying and uncertain results.

Records of its presence may be seen rlaily in the Times, furnished from the Observatory on Ben Nevis, but as yet little notice has been taken of its prevalence at sea, though it has been supposed to be more plentiful there than on land.

During a voyage around the United Kingdom on the s.s. Ceylon in August last, we entered into the investigation of its existence at sea, and used Moffatt's papers' for the purpose, obtained from Negretti and Zambra. They were exposed in a perforated light wooden box, hung up in the open air on the deck of the ship in the shade, and noted and changed twice a day.

It was found most prevalent in Cork Harbour (4), less so in Bantry Bay (2) and Oban Harbour (2), and nearly absent in Kingstown Harbour (I) and Leith Roads (I).

In the open sea it was most shown in the Irish Channel (4) and off the Lands End (4); next in the North Seas (3) and in the English Channel (2), and least in the Irish seas (I) and western coasts of Scotland (I).

Ozone was found to be indicated in greater intensity during the prevalence of zesterly winds in the English and Irish Channels, and Atlantic seas and Dutch seas, and less with easterly winds prevailing in the Irish seas, Firth of Forth, and west coasts of Scotland.

The velocity of the winds seemed also to create a higher manifestation, as was seen during the gale from the south-west in Cork Harbour and the fresh north-westerly breezes on the south coasts of Ireland and east coasts of England. None, however, of the observations approached those registered in the Times from Ben Nevis (8-9), which amounted to double those noticed in the seas around our coasts during the same period (August), supposing that the same papers and scale (Moffatt's) were used for both sets of observations.

Ozone was also found to exist in the cabin of the ship both day and night, but at a half intensity to that on the deck, due probably to the great difference in the movement of the air in the two places.

The degrees of manifestation of ozone at sea here shown by no means come up to expectation that it prevailed in all its potentiality on the ocean, but of course a whole year's observation would be required to enlighten the subject and furnish a comparison with that on the land.

Again, it may be possible that altitude may have something to do with its prevalence, more or less, as it appeared more on the top of Ben Nevis than on the level of the seas of the same coasts near it and at the same period of the year (August).

Should this idea be of any significance it might be as well to search for manifestations of ozone at the base as well as on the top of mountains, and if similar results followed to these here pointed out it would establish the reputation of high level sites for great salubrity of atmosphere. August, 1885

W. J. BLACK

\section{THE INTERNATIONAL BOTANICAL} 1885

THE International Botanical and Horticultural Congress met at'Antwerp on Sunday, August 2, in the hall of the Artistic, Literary and Scientific Club, the opening meeting being honoured by the presence of a good many ladies. The gathering was a representative one, and included many well-known European botanists and horticulturists. The Burgomaster of Antwerp opened the procecdings with a few appropriate remarks, and Prof. Ed. Morren, of Liége, having been made President of the Congress, took the chair, and a discussion was held on the flora of the Congo. After a short discussion the meeting adjourned to the Exhibition building, where the International Horticultural Show was being held, and which was formally opened at one o'clock. Many of the plants exhibited were of great interest, and the whole of the collections were nicely and artistically arranged. At five o'clock the Congress visited the Plantin Museum, the old printing office of the Plantin Moretus family. The Museum is full of interest, and as the printing office from which the works of Lobel, Dodonaeus, and Clusius issued, doubly interesting to all botanists. Through the kindness of the Burgomaster of Antwerp a sheet had been struck off for the members of the Congress, so that each was presented with a souvenir of the three great herbalists. 